\title{
KONTRIBUSI INVESTASI DAN EKSPOR TERHADAP PERTUMBUHAN EKONOMI DI PROVINSI SULAWESI SELATAN
}

\author{
Zulkifli $^{1}$
}

\section{ABSTRAK}

Ekspor dan investasi memegang peran penting dalam kegiatan perekonomian suatu negara. Ekspor akan menghasilkan devisa yang akan digunakan untuk membiayai impor bahan baku dan barang modal yang diperlukan dalam proses produksi yang akan membentuk nilai tambah. sedangkan Investasi merupakan pengeluaran yang ditujukan untuk meningkatkan atau mempertahankan stok barang modal. Tujuan penelitian ini adalah Untuk mengetahui pengaruh investasi dan ekspor terhadap pertumbuhan ekonomi Propinsi Sulawesi Selatan. Metode yang digunakan dalam penelitian ini adalah analisis regeresi berganda dengan menggunakan data periode tahun 2003 sampai 2015.

Hasil peneliian ini menunjukkan Investasi berpengaruh positif dan signifikan terhadap pertumbuhan ekonomi. Peningkaan Investasi Propinsi Sulawesi Selatan akan menyebabkan pertumbuhan ekonomi Propinsi Sulawesi Selatan. 2). Ekspor berpengaruh positif dan signifikan terhadap pertumbuhan ekonomi.peningkatan Ekspor Propinsi Sulawesi Selatanmenyebabkan pertumbuhan ekonomi Propinsi Sulawesi Selatan meningkat.

Kata kunci: Investasi, Ekspor, Pertumbuhan Ekonomi, Kontribusi

\section{PENDAHULUAN}

Pembangunan pada dasarnya merupakan proses multidimensial yang meliputi perubahan struktur sosial, perubahan dalam sikap hidup masyarakat dan perubahan dalam kelembagaan (institusi) nasional. Pembangunan juga meliputi perubahan dalam tingkat pertumbuhan ekonomi, pengurangan ketimpangan pendapatan dan pemberantasan kemiskinan.(Todaro, 2004). Salah satu indikator keberhasilan pembangunan dalam suatu wilayah adalah pertumbuhan ekonomi.Pertumbuhan itu sendiri dapat diartikan sebagai gambaran mengenai dampak dari kebijakan-kebijakan pemerintah yang dilaksanakan dalam bidang ekonomi. Menurut Boediono (1999), pertumbuhan ekonomi merupakan tingkat pertambahan dari pendapatan nasional. Dengan demikian, pertumbuhan ekonomi

1 STAIN Watampone, nalling inp@ymail.com 
merupakan sebagai proses kenaikan output per kapita dalam jangka panjang dan merupakan ukuran keberhasilan pembangunan.

Salah satu indikator keberhasilan pelaksanaan pembangunan yang dapat dijadikan tolok ukur secara makro adalah pertumbuhan ekonomi.Yang dicerminkan dari perubahan Produk Domestik Regional Bruto (PDRB) dalam suatu wilayah (Suryono,2010). Sementara itu, potensi ekonomi pada suatu wilayah dapat diukur dari kontribusi masing-masing sektor terhadap nilai Produk Domestik Regional Bruto (PDRB). Provinsi Sulawesi Selatan merupakan salah satu wilayah Indonesia, jika dilihat dari Produk Domestik Regional Bruto (PDRB) tahun 20052014 mengalami perkembangan yang berfluktuatif, begitupula jika dilihat dari pertumbuhannya yang berfluktuatif dimana tahun 2006 pertumbuhan PDRB Provinsi Sulawesi Selatan mencapai 6 6.72\%, tahun 2007 turun menjadi 6.34\%, tahun 2008 meningkat menjadi $7.79 \%$, tahun 2009 turun menjadi 6.23\%, tahun 2010 meningkat menjadi 8.19\%, tahun 2011 turun menjadi $7.62 \%$, dan tahun 2012 meningkat menjadi 8.37\%.

Saat ini banyak studi tentang pertumbuhan ekonomi. Beberapa studi empiris yang telah dilakukan, baik di negara maju maupun di negara berkembang termasuk Indonesia adalah Khan dan Reinhart (1990), Sinha (1999), Far (2000), dan Amir (2004). Diantara studi-studi tersebut mengemukakan pentingnya peningkatan ekspor dan investasi untuk memacu pertumbuhan ekonomi.

Ekspor dan investasi memegang peran penting dalam kegiatan perekonomian suatu negara. Ekspor akan menghasilkan devisa yang akan digunakan untuk membiayai impor bahan baku dan barang modal yang diperlukan dalam proses produksi yang akan membentuk nilai tambah. Pertumbuhan ekspor di Provinsi Sulawesi Selatan terlihat mengalami pertumbuhan yang berfluktuatif, Ekspor Sulawesi Selatan tahun 2008 ekspor 3.41\%, tahun 2009 mengalami pertumbuhan negative sebesar $-12.51 \%$, tahun 2010 pertumbuhan ekspor Provinsi Sulawesi Selatan yaitu sebesar 1.71\%, tahun 2011 pertumbuhan ekspor Provinsi Sulawesi Selatan kemabali mengalami pertumbuhan negative yaitu sebesar 2.05\% kemudian tahun 2012 pertumbuhan ekspor Provinsi Sulawesi Selatan mengalami pertumbuhan sebesar $13.18 \%$

Selain ekspor, investasi juga mempunyai peranan penting dalam meningkatkan pertumbuhan ekonomi di Provinsi Sulawesi Selatan, pertumbuhan investasi Provinsi Sulawesi Selatan terlihat mengalami pertumbuhan yang 
berfluktuatif tahun 2006 investasi di Provinsi Sulawesi Selatan tumbuh sebesar $31.50 \%$, tahun 2007 tumbuh sebesar 39.53\%,- tahun 2008 pertumbuhan investasi di Provinsi Sulawesi Selatan lebih rendah dibandingkan tahun sebelumnya yaitu sebesar 37.36\%, kemudian tahun 2009 sampai 2011 terlihat mengalami penurunan yaitu masing masing sebesar 22\% untuk tahun 2009, tahun 2010 mengalami pertumbuhan negative yaitu sebesar $-26.11 \%$, tahun 2011 masih mengalami pertumbuhan negative yaitu sebesar $-26.11 \%$ dan tahun 2012 sudah mengalami pertumbuhan positif yaitu sebesar $10.74 \%$. Berdasarkan latar belakang yang telah diuraikan maka penulis tertarik untuk melakukan penelitian dengan judul “ Kontribusi Investasi Dan Ekspor Terhadap Pertumbuhan Ekonomi Di Provinsi Sulawesi .

\section{TINJ AUAN PUSTAKA}

\section{Investasi}

Keynes, menyatakan bahwa yang menjadi pertimbangan dalam melakukan investasi adalah perbandingan antara besarnya laba yang diharapkan dengan biaya penggunaan dana atau tingkat bunga. Keynes ini mengisyaratkan bahwa jika tingkat laba yang diharapkan lebih besar dari tingkat bunga maka investasi boleh dilakukan. Pendapat Keynes ini mungkin terlalu sederhana jika dibandingkan dengan keadaan sekarang ini, karena investor tidak hanya mempertimbangkan suku bunga sebagai satu-satunya pertimbangan dalam melakukan investasi.

Oleh karena itu Sudono Sukirno membuat rincian yang menjadikan foktorfaktor utama yang menentukan tingkat investasi sebagai berikut :

1. Tingkat keuntungan investasi yang diramalkan akan diperoleh.

2. Tingkat bunga.

3. Ramalan mengenai keadaan ekonomi dimasa depan.

4. Kemajuan tehnologi.

5. Tingkat pendapatan nasional dan perubahan-perubahannya.

6. Keuntungan yang diperoleh perusahaan-perusahaan. (Sukirno, 2003)

Dari enam faktor penting yang menentukan jumlah investasi tersebut diatas, ada dua faktor yang lebih penting untuk menerangkan mengenai sebabsebab perubahan investasi yang lebih penting dari faktor-faktor lainnya. Faktor tersebut adalah tingkat keuntungan yang diramalkan dan tingkat bunga. 


\section{Iklim Investasi}

Secara sederhana dapat dikatakan bahwa iklim investasi mencerminkan sejumlah faktor yang berkaitan dengan lokasi tertentu yang membentuk kesempatan dan insentif bagi pemilik modal untuk melakukan usaha atau investasi secara produktif dan berkembang. Lebih konkritnya lagi, "Iklim usaha atau investasi yang kondusif adalah iklim yang mendorong seseorang melakukan investasi dengan biaya dan resiko serendah mungkin di satu sisi, dan bisa menghasilkan keuntungan jangka panjang setinggi mungkin, di sisi lain. (Stern, 2002).

Ada sejumlah faktor yang sangat berpengaruh pada baik-tidaknya iklim berinvestasi di Indonesia. Faktor-faktor tersebut tidak hanya menyangkut stabilitas politik dan sosial, tetapi juga stabilitas ekonomi, kondisi infrastruktur dasar (listrik, telekomunikasi dan prasarana jalan dan pelabuhan), berfungsinya sektor pembiayaan dan pasar tenaga kerja (termasuk isu-isu perburuhan), regulasi dan perpajakan, birokrasi (dalam waktu dan biaya yang diciptakan), masalah good governance termasuk korupsi, konsistensi dan kepastian dalam kebijakan pemerintah yang langsung maupun tidak langsung mempengaruhi keuntungan neto atas biaya resiko jangka panjang dari kegiatan investasi, dan hak milik mulai dari tanah sampai kontrak.

\section{Penanaman Modal Dalam Negeri (PMDN)}

Investasi merupakan pengeluaran yang ditujukan untuk meningkatkan atau mempertahankan stok barang modal yang terdiri dari mesin, pabrik, kantor dan produk-produk tahan lama lainnya yang digunakan dalam proses produksi (Mulyadi, 1990).

Investasi merupakan penundaan konsumsi sekarang untuk digunakan didalam produksi yang efisien selama periode waktu yang tertentu. (Jogiyanto, 2003). Selain itu investasi dapat juga diartikan sebagai pengeluaran oleh sektor produsen swasta untuk pembelian barang-barang atau jasa-jasa guna penambahan stok barang dan peralatan perusahaan (Boediono, 1986).

Faktor-faktor penentu investasi sangat tergantung pada situasi di masa depan yang sulit untuk diramalkan, maka investasi merupakan komponen yang paling mudah berubah. Usaha untuk mencatat nilai penanaman modal yang dilakukan dalam satu tahun tertentu yang digolongkan sebagai investasi, meliputi 
pengeluaran atau pembelanjaan untuk seluruh nilai pembelian para pengusaha atas barang modal dan membelanjakan untuk mendirikan industri-industri, pengeluaran masyarakat untuk mendirikan tempat tinggal, dan pertambahan dalam nilai stok barang-barang perusahaan yang berupa bahan mentah, barang yang belum diproses dan barang jadi.

Penanaman modal dalam negeri memberikan peranan dalam pembangunan ekonomi di negara-negara sedang berkembang hal ini terjadi dalam berbagai bentuk. Modal Investasi mampu mengurangi kekurangan tabungan dan melalui pemasukan peralatan modal dan bahan mentah, dengan demikian menaikkan laju pemasukan modal. Selain itu tabungan dan investasi yang rendah mencerminkan kurangnya modal di negara keterbelakangan teknologi. Bersamaan dengan modal uang dan modal fisik, modal Investasi yang membawa serta keterampilan teknik, tenaga ahli, pengalaman organisasi, informasi pasar, teknik-tekink produksi maju, pembaharuan produk dan lain-lain. Selain itu juga melatih tenaga kerja setempat pada keahlian baru. Semua ini pada akhirnya akan mempercepat pembangunan ekonomi negara terbelakang.

\section{Penanaman Modal Asing (PMA)}

Dalam Pasal 5 ayat (2) Undang-Undang Nomor 25 Tahun 2007 tentang Penanaman Modal telah ditentukan secara jelas tentang bentuk hukum perusahaan penanaman modal asing.Penanaman modal asing wajib dalam bentuk perseroan terbatas. Secara lengkap, bunyi Pasal 5 ayat (2) UndangUndang Nomor 25 Tahun 2007 tentang Penanaman modal: "penanaman modal asing wajib dalam bentuk perseroan terbatas berdasarkan hokum Indonesia dan berkedudukan di wilayah negara Republik Indonesia, kecuali ditentukan lain oleh undang-undang."

Penanaman modal asing di Indonesia dapat dilakukan oleh pihak asing/perorangan atau badan hukum ke dalam suatu perusahaan yang seratus persen diusahakan oleh pihak asing atau dengan menggabungkan modal asing itu dengan modal nasional. Menurut Ismail Suny ada 3 (tiga) macam kerjasama antara modal asing dengan modal nasional berdasarkan undang-undang penanaman modal asing No. 1 Tahun 1967 yaitu joint venture, joint enterprise dan kontrak karya. 
Keberadaan penanaman modal asing secara langsung (foreign direct investment) tidak dapat dipungkiri telah memberi banyak manfaat bagi Negara penerima modal (host country), begitu pula bagi investor maupun bagi negara asal (home country). Bagi negara penerima modal (host country) keberadaaan investasi yang ditanamkan oleh investor, khususnya penanaman modal asing secara langsung (foreign direct investment), ternyata telah memberikan dampak positif atau manfaat di dalam pembangunan. Terlepas dari pendapat pro dan kontra terhadap kehadiran investasi asing, namun secara teoritis kiranya dapat dikemukakan, bahwa kehadiran investor asing di suatu negara mempunyai manfaat yang cukup luas (multiplier effect). Manfaat yang dimaksud, yakni kehadiran investor asing dapat menyerap tenaga kerja di Negara penerima modal, dapat menciptakan demand bagi produk dalam negeri sebagai bahan baku, menambah devisa apalagi investor asing yang berorientasi ekspor, dapat menambah penghasilan negara dari sektor pajak, adanya alih teknologi (transfer of technology) maupun alih pengetahuan (transfer of know how). Dilihat dari sudut pandang ini terlihat bahwa, kehadiran investor cukup berperan dalam pembangunan ekonomi suatu negara, khususnya pembangunan ekonomi di daerah dimana FDI menjalankan aktifitasnya.

\section{Ekspor}

Pengertian ekspor menurut keputusan menteri perdagangan dan perindustrian Nomor 182/MPP/KEP/4/1998 tentang ketentuan umum dibidang ekspor, menyatakan bahwa ekspor adalah kegiatan mengeluarkan barang dan jasa dari daerah kepabeanan suatu negara. Adapun daerah kepabeanan sendiri diartikan sebagai wilayah Republik Indonesia yang meliputi wilayah darat, perairan dan ruang udara di atasnya serta tempat-tempat tertentu di zona ekonomi exlusif dan landas kontinen yang di dalamnya berlaku Undang-Undang No.10 tahun 1995 tentang Kepabeanan. Kegiatan ekspor adalah sistem perdagangan dengan cara mengeluarkan barang dari dalam keluar wilayah pabean Indonesia dengan memenuhi ketentuan yang berlaku. Ekspor merupakan nilai semua barang dan jasa yang dijual oleh sebuah negara ke negara lain

Untuk meningkatkan pertumbuhan ekonomi dan pembangunan pada umumnya, setiap negara perlu merumuskan dan menerapkan kebijakankebijakan internasional yang berorientasi ke luar. Dalam semua kasus, 
kemandirian yang didasarkan pada isolasi, baik yang penuh maupun yang hanya sebagian, tetap saja secara ekonomi akan lebih rendah nilainya daripada partisispasi ke dalam perdagangan dunia yang benar-benar bebas tanpa batasan atau hambatan apapun (Todaro\& Smith, $2004: 29$ ).

Ekspor dapat diartikan sebagai kegiatan yang menyangkut produksi barang dan jasa yang diproduksi di suatu negara untuk dikonsumsikan di luar batas negara tersebut. Menurut Samuelson \& Nordhaus (2004;325) Ekspor adalah Barang dan jasa yang diproduksi di dalam negeri dan dibeli oleh orangorang asing. Ekspor maupun impor merupakan faktor penting dalam merangsang pertumbuhan ekonomi suatu negara. Ekspor impor akan memperbesar kapasitas konsumsi suatu negara meningkatkan output dunia, serta menyajikan akses ke sumber-sumber daya yang langka dan pasar-pasar internasional yang potensial untuk berbagai produk ekspor yang mana tanpa produk-produk tersebut, maka negara-negara miskin tidak akan mampu mengembangkan kegiatan dan kehidupan perekonomian nasionalnya.

\section{Teori Basis Ekonomi}

Teori basis ekonomi (economic base teory), mendasarkan pandangannya bahwa laju pertumbuhan ekonomi suatu wilayah ditentukan oleh besarnya peningkatan ekspor dari wilayah tersebut.kegiatan ekonomi dikelompokkan atas kegiatan basis dan non basis. Hanya kegiatan basis yang dapat mendorong pertumbuhan ekonomi wilayah.

Dalam pengertian ekonomi regional, ekspor adalah menjual produk/jasa keluar wilayah baik kewilayah lain dalam negara itu maupun keluar negeri. Pada dasarnya kegiatan ekspor adalah semua kegiatan yang mendatangkan uang dari luar wilayah disebut kegiatan basis. Lapangan kerja dan pendapatan disektor basis adalah fungsi dari permintaan yang bersifat exogenous (tidak tergantung pada kekuatan intern/permintaan lokal), sedangkan kegiatan lain yang bukan kegiatan basis termasuk kedalam kegiatan/sektor service atau pelayanan (non basis). Sektor non basis adalah untuk memenuhi kebutuhan konsumsi lokal, karena sifatnya yang memenuhi kebutuhan lokal, permintaan sektor ini sangat dipengaruhi oleh tingkat pendapatan masyarakat setempat, oleh karena itu kenaikannya sejalan dengan kenaikan pendapatan masyarakat setempat. Dengan demikian sektor ini terikat terhadap kondisi ekonomi setempat dan tidak 
bisa berkembang melebihi pertumbuhan ekonomi wilayah, atas dasar anggapan diatas, satu-satunya sektor yang bisa meningkatkan perekonomian wilayah melebihi pertumbuhan alamiah adalah sektor basis.( Robinson Tarigan;28).

\section{Teori Keunggulan Komparatif}

\section{Teori keunggulan komparatif David Ricardo}

David Ricardo seorang tokoh aliran klasik menyatakan bahwa nilai penukaran ada jikalau barang tersebut memiliki nilai kegunaan Dengan demikian sesuatu barang dapat ditukarkan bilamana barang tersebut dapat digunakan. Seseorang akanmembuat sesuatu barang, karena barang itu memiliki nilai guna yang dibutuhkan oleh orang. Teori perdagangan internasional diketengahkan oleh David Ricardo yang mulai dengan anggapan bahwa lalu lintas pertukaran internasional hanya berlaku antara dua negara yang diantara mereka tidak ada tembok pabean, serta kedua negara tersebut hanya beredar uang emas. Ricardo memang memanfaatkan hukum pemasaran bersama-sama dengan teori kuantitas uang untuk mengembangkan teori perdagangan internasional. Walaupun suatu negara memiliki keunggulan absolut, akan tetapi apabila dilakukan perdagangan tetap akan menguntungkan bagi kedua negara yang melakukan perdagangan.

Teori perdagangan telah mengubah dunia menuju globalisasi dengan lebih cepat. Kalau dahulu negara yang memiliki keunggulan absolut enggan untuk melakukan perdagangan, berkat law of comparative costs dari Ricardo, Inggris mulai kembali membuka perdagangannya dengan negara lain. Pemikiran kaum klasik telah mendorong diadakannya perjanjian perdagangan bebas antara beberapa Negara Teori comparative advantage telah berkembang menjadi dynamic comparative advantage yang menyatakan bahwa keunggulan komparatif dapat diciptakan. Oleh karena itu penguasaan teknologi dan kerja keras menjadi faktor keberhasilan suatu negara. Bagi negara yang menguasai teknologi akan semakin diuntungkan dengan adanya perdagangan bebas ini, sedangkan negara yang hanya mengandalkan kepada kekayaan alam akan kalah dalam persaingan internasional. David Ricardo membagi teori Keunggulan komparatif berdasarkan

a) Cost Comparative Advantage (Labor efficiency) 
Menurut teori cost comparative advantage (labor efficiency), suatu Negara akan memperoleh manfaat dari perdagangan internasional jika melakukan spesialisasi produksi dan mengekspor barang di mana Negara tersebut dapat berproduksi relatif lebih efisien serta mengimpor barang di mana negara tersebut berproduksi relatif kurang/tidak efisien.

b) Production Comperative Advantage (Labor productifity)

Suatu negara akan memperoleh manfaat dari perdagangan internasional jika melakukan spesialisasi produksi dan mengekspor barang di mana negara tersebut dapat berproduksi relatif lebih produktif serta mengimpor barang di mana Negara tersebut berproduksi relatif kurang/tidak produktif.

\section{Teori Hecksher Ohlin}

Teori Heckscher-Ohlin ( $\mathrm{H}-\mathrm{O})$ menjelaskan beberapa pola perdagangan dengan baik, negara-negara cenderung untuk mengekspor barang-barang yang menggunakan faktor produksi yang relatif melimpah secara intensif. Menurut Heckscher-Ohlin, suatu negara akan melakukan perdagangan dengan negara lain disebabkan negara tersebut memiliki keunggulan komparatif yaitu keunggulan dalam teknologi dan keunggulan faktor produksi.

Comparative Advantage dari suatu jenis produk yang dimiliki masingmasing negara akan ditentukan oleh struktur dan proporsi faktor produksi yang dimilikinya. Masing-masing negara akan cenderung melakukan spesialisasi produksi dan mengekspor barang tertentu karena negara tersebut memiliki faktor produksi yang relatif banyak dan murah untuk memproduksinya. Sebaliknya masing-masing negara akan mengimpor barang-barang tertentu karena negara tersebut memilki faktor produksi yang relatif sedikit dan mahal untuk memproduksinya.

\section{Teori Keunggulan kompetitif}

Menurut Porter (1990), dalam persaingan global saat ini, suatu bangsa atau negara yang memiliki competitive advantage of nation dapat bersaing $\mathrm{di}$ pasar internasional bila memiliki empat faktor penentu dan dua faktor pendukung. Empat faktor utama yang menentukan daya saing suatu komoditi adalah kondisi faktor (factor condition), kondisi permintaan (demand condition), industri terkait dan industri pendukung yang kompetitif (related and supporting industry), serta 
kondisi struktur, persaingan dan strategi industri (firm strategy, structure, and rivalry).Ada dua faktor yang mempengaruhi interaksi antara keempat faktor tersebut yaitu faktor kesempatan (chance event) dan faktor pemerintah (government).Secara bersama-sama faktor-faktor ini membentuk sistem dalam peningkatan keunggulan daya saing yang disebut Porter's Diamond Theory.

\section{Pertumbuhan Ekonomi}

Proses pembangunan pada dasarnya bukanlah sekedar fenomena ekonomi semata. Pembangunan tidak sekedar ditunjukkan oleh prestasi pertumbuhan ekonomi yang dicapai oleh suatu negara, namun lebih dari itu pembangunan memiliki perspektif yang luas. Beberapa ahli ekonomi seperti Schumpeter dan Hicks, telah menarik perbedaan yang lebih lazim antara istilah perkembangan ekonomi dan pertumbuhan ekonomi. Perkembangan ekonomi mengacu pada masalah negara terbelakang sedang pertumbuhan mengacu pada masalah negara maju.

Menurut Sadono Sukirno $(2008 ; 9)$ pertumbuhan ekonomi dapat diartikan sebagai perkembangan kegiatan dalam perekonomian yang menyebabkan barang dan jasa yang diproduksikan dalam masyarakat bertambah, masalah pertumbuhan ekonomi dapat dipandang sebagai masalah makroekonomi dalam jangka panjang, dari satu periode keperiode lainnya kemampuan sesuatu Negara menghasilkan barang dan jasa akan meningkat, kemampuan yang meningkat ini disebabkan karena factor-faktor produksi akan selalu mengalami pertambahan dalamjumlah dan kualitasya. Investasi akan menambah jumlah barang modal, teknologi yang digunakan berkembang, disamping itu tenaga kerja bertambah sebagai akibat perkembangan penduduk, dan pengalaman kerja dan pendidikan menambah kemampuan mereka. Perkembangan kemampuan memproduksi barang dan jasa sebagai akibat pertambahan factor-faktor produksi pada umumnya tidak selalu diikuti pertambahan produksi barang dan jasa yang sama besarnya.

Pertumbuhan ekonomi didefiniskan sebagai penjelasan mengenai faktorfaktor yang menentukan kenaikan output per kapita dalam jangka panjang, dan penjelasan mengenai bagaimana faktor-faktor tersebut berinteraksi satu sama lain, sehingga terjadi proses pertumbuhan (Boediono; 1999). 
Pertumbuhan ekonomi adalah salah satu indikator yang amat penting dalam melakukan analisis tentang pembangunan ekonomi yang terjadi pada suatu negara. Pertumbuhan ekonomi menunjukkan sejauhmana aktivitas perekonomian akan menghasilkan tambahan pendapatan masyarakat pada suatu periode tertentu. Karena pada dasarnya aktivitas perekonomian adalah suatu proses penggunaan faktor-faktor produksi untuk menghasilkan output, maka proses ini pada gilirannya akan menghasilkan suatu aliran balas jasa terhadap faktor produksi yang dimiliki oleh masyarakat. Dengan adanya pertumbuhan ekonomi maka diharapkan pendapatan masyarakat sebagai pemilik faktor produksi juga akan turut meningkat. (Susanti, dkk; 2000).

Todaro (2000) menjelaskan bahwa ada tiga faktor atau komponen utama dalam pertumbuhan ekonomi dari setiap bangsa, yaitu :

1. Akumulasi Modal, yang meliputi semua bentuk atau jenis investasi baru yang ditanamkan pada tanah, peralatan fisik dan sumbersaya manusia.

2. Pertumbuhan penduduk, yang beberapa tahun selanjutnya dengan sendirinya membawa pertumbuhan angkatan kerja

3. Kemajuan teknologi.

Akumulasi modal (capital accunulation) terjadi apabila sebagian dari pendapatan ditabung dan diinvestasikan kembali dengan tujuan memperbesar output dan pendapatan. Akumulasi modal akan menambah sumberdaya baru (contohnya, pembukaan tanah-tanah yang semula tidak digunakan) atau meningkatkan kualitas sumberdaya (misalnya, perbaikan sistim irigasi, pengadaan pupuk, pestisida).

Todaro (2000) menjelaskan bahwa akumulasi modal (Capital Accumulation) terjadi apabila sebagian pendapatan ditabung dan diinvestasikan kembali dengan tujuan memperbesar output dan pendapatan dikemudian hari. Pengadaan pabrik baru, mesin-mesin, peralatan dan bahan baku meningkatkan stok modal secara fisik suatu negara (yakni nilai riil netto atas seluruh barang modal produktif secara fisik) dan hal itu jelas memungkinkan akan terjadinya peningkatan output dimasa-masa mendatang. Investasi dalam pembinaan sumberdaya manusia juga meningkatkan kualitasnya sehingga pada akhirnya akan membawa dampak positif yang sama terhadap angka produksi, bahkan akan lebih besar lagi mengingat terus bertambahnya jumlah manusia. 
Pendidikan formal, program pendidikan dan pelatihan dalam kerja atau magang, kursus-kursus dan aneka pendidikan infomal lainnya perlu diefektifkan untuk mencetak tenaga-tenaga terdidik dan sumberdaya manusia yang terampil melalui investasi langsung dalam pembangunan.

Menurut Singer (Jhingan; 1994) pembentukan modal terdiri dari barang yang nampak seperti pabrik, alat-alat dan mesin, maupun barang yang tidak nampak seperti pendidikan bermutu tinggi, kesehatan, tradisi ilmiah dan penelitian. Untuk memahami bagaimana akumulasi modal dan perubahan teknologi dapat menggerakkan perekonomian, maka model pertumbuhan neoklasik yang diperkenalkan oleh Robert Solow menggambarkan suatu perekonomian dimana output merupakan hasil kerja dari dua jenis input, yaitu modal dan tenaga kerja. (Samuelson; 1995)

Investasi (sebagai salah satu komponen penting dari $A D$ ) merupakan suatu faktor krusial bagi kelangsungan proses pembangunan ekonomi (Sustainable Development), atau pertumbuhan ekonomi jangka panjang. Pembangunan ekonomi melibatkan kegiatan-kegiatan produksi disemua sektor ekonomi, dan untuk kegiatan pembangunan itu diperlukan dana untuk membiayainya yang disebut dana investasi. (Tambunan;2001).

Tambunan (2001) dijelaskan bahwa pertumbuhan ekonomi sangat ditentukan pada ketersediaan dan kualitas dari faktor-faktor produksi seperti SDM, kapital, teknologi, bahan baku, entrepreneurship, dan energi. Pertumbuhan ekonomi ditentukan oleh faktor internal yang dapat dibedakan antara lain faktor ekonomi dan faktor non ekonomi khususnya politik dan sosial sedangkan faktor eksternal didominasi oleh faktor-faktor ekonomi seperti perdagangan internasional dan pertumbuhan ekonomi kawasan atau dunia.

Proses pembangunan dilihat sebagai perubahan struktural ditandai dengan perubahan yang bersifat multi dimensional yaitu suatu perubahan dari konstelasi ekonomi yang mengalami stagnasi kearah perimbangan-perimbangan keadaan yang sudah mengandung gerak kekuatan dinamika dalam perkembangannya. Perubahan struktural menyangkut perubahan-perubahan pada struktur dan komposisi produk nasional, pada kesempatan kerja produktif, pada ketimpangan antar sektor, antar daerah dan antar golongan masyarakat, pada kemiskinan dan kesenjangan antara golongan berpendapatan rendah dan tinggi. 


\section{METODE PENELITIAN}

Dalam penelitian ini, digunakan metode komparatif dan kuantitatif, yaitu membandingkan suatu permasalahan dan menganalisis data dan hal-hal yang berhubungan dengan angka-angka atau rumus-rumus perhitungan yang digunakan untuk menganalisis masalah yang sedang diteliti.

\section{Pengaruh Investasi dan Ekspor Terhadap Pertumbuhan Ekonomi Provinsi}

\section{Sulawesi Selatan}

Model analisis yang di gunakan untuk menganalisis Pengaruh investasi dan ekspor (Variable independent) terhadap pertumbuhan ekonomi Provinsi Sulawesi Selatan(Variabel dependent)adalah analisis regresi berganda.

Model yang digunakan dalam penelitian ini adalah :

$$
Y_{t}=\beta_{0}+\beta_{1} X 1_{t}+\beta_{2} X 2_{t}+e_{i}
$$

Keterangan :

$\begin{array}{lll}\mathrm{Y}_{\mathrm{t}} & : & \text { Pertumbuhan Ekonomi } \\ \mathrm{X} 1 & : & \text { Investasi } \\ \mathrm{X} 2 & : & \text { Ekspor } \\ \beta_{0} & : & \text { Konstanta } \\ \beta_{1} \beta_{2} & : & \text { Nilai Koefisien X1 dan X2 } \\ \mathrm{e}_{\mathrm{i}} & : & \text { Error Term. }\end{array}$

\section{Uji Asumsi Klasik}

a). Uji Normalitas

Uji Normalitas bisa dilakukan dengan teknik Kolmogorov-Smirnov. Berdasarkan hasil uji normalitas tersebut dapat disimpulkan data pertumbuhan ekonomi, investasi dan ekspor berdistribusi normal dan dapat dilakukan uji regresi berganda

\section{b). Uji Autokorelasi}

Uji Autokorelasi dilakukan dengan tujuan untuk mendeteksi ada atau tidaknya serial korelasi dari error term yang terdapat dalam suatu persamaan regresi. Gejala serial korelasi dalam konteks time series terjadi bila error term pada suatu periode tertentu berpengaruh kepada periode waktu berikutnya, atau dengan kata lain jika error term dari periode waktu berlainan saling berkorelasi. 
Metode yang digunakan untuk menguji serial korelasi ini yaitu dengan menggunakan uji Durbin-Watson

Berdasarkan hasil uji autokorelasi dapat disimpulkan bahwa pada model tersebut tidak terdapat keberadaan masalah autokorelasi dengan tingkat kepercayaan $95 \%$.

c). Uji Multikolinearitas

Multikolinieritas menunjukkan adanya hubungan yang kuat diantara variabel bebas dalam model regresi.Jika terdapat Multikolinieritas maka koefisien regresi menjadi tidak akurat dalam mencerminkan perubahan variabel $Y$ dan tingkat kesalahannya menjadi sangat besar.Sebagai indikator ada tidaknya multikolinieritas diantara variabel bebas dalam model regresi yang diperoleh pada penelitian ini digunakan nilai Variance Inflation Factors (VIF). Berdasarkan hasil olah data diperoleh nilai Variance Inflation Factors (VIF) untuk semua variabel independent dibawah 10, dengan demikian dapat disimpulkan bahwa situasi multikolinearitas tidak terjadi dan seluruh variabel bebas dapat dipertahankan untuk dianalisis.

d). Uji Heteroskedastisitas

Uji Heteroskedastisitas bertujuan untuk menguji apakah dalam model regresi terjadi ketidaksamaan varians dari residual satu pengamatan ke pengamatan yang lain. Model regresi yang baik yaitu tidak terjadi heteroskedastisitas. Untuk menentukan apakah model yang digunakan dalam penelitian ini terbebas dari masalah Heteroskedastisitas maka dilakukan uji Glejser. Bila variabel bebas secara statistik signifikan mempengaruhi residual maka model dalampenelitian ini terdapat gejala Heteroskedastisitas dan sebaliknya jika Bila variabel bebas secara statistik tidak signifikan mempengaruhi residual maka model dalam penelitian ini tidak terdapat gejala Heteroskedastisitas. Berdasarkan hasil olah data dapat dilihat bahwa nilai statistiik dari seluruh varaibel independen tidak ada yang signifikan secara statistik dengan demikian dapat disimpulkan bahwa masalah heteroskedastisitas tidak terjadi dan seluruh variabel bebas. 


\section{Analisis Regresi Berganda}

Berdasarkan hasil olah data dengan menggunakan SPSS 20 diperoleh hasil sebagai berikut :

Tabel 1. Nilai Koefisien Regresi

\begin{tabular}{|l|l|l|}
\hline Variabel & Nilai Koefisien Regresi & Signifikansi \\
\hline (Constant) & 1.267 & \\
\hline Investasi (X1) & 2.630 & .196 \\
\hline Ekspor(X2) & 9.924 & .001 \\
\hline
\end{tabular}

Sumber : Hasil olah data

Jika memperhatikan kembali bentuk persamaan yang digunakan dalam penelitian ini :

$$
\operatorname{Ln} Y=\beta_{0}+\beta_{1} \operatorname{Ln} X_{1}+\beta_{2} \operatorname{LnX} X_{2}+\text { ei. }
$$

Dengan demikian persamaan model menjadi :

$$
Y=1.267+2.630 X_{1}+9.924 X_{2}+e i
$$

Nilai constant $\left(\beta_{0}\right)$

Berdasarkan tabel diatas, dimana nilai constant $\left(\beta_{0}\right)$ sebesar 1.267 menyatakan bahwa jika tidak ada perubahan Investasi (X1) dan ekspor (X2) maka pertumbuhan ekonomi (Y)sebesar 1.267\%.

Investasi (X1)

Berdasarkan tabel diatas dimana nilai koefisien regresi sebesar 2.630 menyatakan bahwa setiap penambahan Rp 1 Investasi (X1) maka pertumbuhan ekonomi (Y) meningkat sebesar 2.630 persen dan sebaliknya jika investasi (X1) turun sebesar Rp.1 maka pertumbuhan ekonomi $(Y)$ turun sebesar 2.630 persen. Arah hubungan antara investasi (X1) dengan pertumbuhan ekonomi (Y)diProvinsi Sulawesi Selatan adalah searah (+)., dimana kenaikan atau penurunan Investasi akan mengakibatkan kenaikan dan penurunan pertumbuhan ekonomi Provinsi Sulawesi Selatan 
Ekspor (X2)

Berdasarkan tabel diatas dimana nilai koefisien regresi sebesar 9.924 menyatakan bahwa setiap peningkatan Rp. 1 Ekspor (X2)maka pertumbuhan ekonomi (Y) meningkat sebesar sebesar $9.924 \%$ dan sebaliknya jika ekspor (X2)turun sebesar Rp. 1 maka pertumbuhan ekonomi (Y) turun sebesar 9.924 \%. Arah hubungan antara ekspor (X2) dengan pertumbuhan ekonomi $(\mathrm{Y})$ diProvinsi Sulawesi Selatan adalah searah (+). dimana kenaikan atau penurunan Ekspor (X2)akan mengakibatkan kenaikan dan penurunan pertumbuhan ekonomi (Y)di Provinsi Sulawesi Selatan

\section{Analisis Koefisien Determinasi Antara Variabel Investasi dan Ekspor Terhadap Pertumbuhan Ekonomi Provinsi Sulawesi Selatan}

Berdasarkan hasil olah data dengan menggunakan spss.20 diperoleh hasil sebagai berikut :

Tabel 2

Nilai koefisien Determinasi

\section{Model Summary}

\begin{tabular}{|l|l|l|l|l|l|}
\hline Model & $R$ & R Square & $\begin{array}{l}\text { Adjusted } \\
\text { Square }\end{array}$ & $\begin{array}{l}\mathrm{R} \\
\text { Std. Error of } \\
\text { the Estimate }\end{array}$ \\
\hline 1 & $.923^{\mathrm{a}}$ & .853 & .811 & .06130 \\
\hline
\end{tabular}

a. Predictors: (Constant), ekspor, Investasi

Dari hasil pengolahan data melalui SPSS 20 pada tabel diatas diperoleh nilai adjusted $R$ Square sebesar 0.853 yang artinya bahwa $85.30 \%$ variasi perubahan pertumbuhan ekonomi dapat dijelaskan variabel investasi (X1) dan ekspor (X2). Sedangkan selebihnya sebesar $14.70 \%$ dipengaruhi oleh variabel lain.

\section{KESIMPULAN}

Variabel investasi dan ekspor berpengaruh positif dan signifikan terhadap pertumbuhan ekonomi di Provinsi Sulawesi Selatan. Hal ini berarti setiap peningkatan ekspor Propinsi Sulawesi Selatan akan meningkatkan pertumbuhan ekonomi Propinsi Sulawesi Selatan 


\section{Daftar Pustaka}

Akhirman, S.Sos., MM (2012) Pengaruh PDB, jumlah penduduk, nilai ekspor, investasi (PMA, PMDN), laju inflasi dan tenaga kerja terhadap pertumbuhan ekonomi Provinsi Kepulauan Riau tahun 2005-2010, JEMI, Vol.3, No. 1, Juni 2012 Universitas Maritim Raja Ali Haji

Basri, Faisal, Haris Munandar, 2003. Lanskap Ekonomi Indonesia. Jakarta. Kencana Prenada Media Group.622 hal.

Boediono, 1992.Teori Pertumbuhan Ekonomi seri Sinipsis, Balai Penelitian Fakultas Ekonomi Universitas Gajah Mada.

Djojohadikusumo,Sumitro, 1994. Dasar Teori Ekonomi Pertumbuhan dan Ekonomi Pembangunan. Jakarta. LP3ES. 376 hal.

Djoyohadikusumo, Soemitro, 1986. Indonesia Dalam Perkembangan Dunia : Kini Dan Masa Datang. Jakarta. LP3ES.

Jhingan, M.L. 2008. Ekonomi Pembangunan dan Perencanaan. Raja Grafindo Persada. Jakarta.

Kuznets, Simon. 1965. Ekonomi Pembangunan. Yogyakarta. Balai Penilitian Fakultas Ekonomi Universitas Gajah Mada.

Lincoln Arsyad (1999) Pengantar perencanaan dan pembangunan Ekonomi Daerah BPFE Yogyakarta

Mankiw, N.G. 2007.Makroekonomi.E disi 6.Erlangga. Jakarta

Michael P. Todaro, Stephen C. Smith (2006) Pembangunan ekonomi edisi kesembilan Penerbit Erlangga Jakarta

Mudrajad Kuncoro (2000) Ekonomi Pembangunan teori,Masalah dan kebijakan. UPP AMPYKPN Yogyakarta

Paul A. Samuelson, William D Nordhaus, 2001 ilmu ekonomi makro.PT. Media Global Edukasi Jakarta

Richardson, W. Harry, (terjemahan) Paul Sitohang, 1977.Elements of Regional Economic, Jakarta.Lembaga Penelitian Fakultas Ekonomi Universitas Indonesia.

Ropingi, Agustono, Catur TBJP. 2009. Analisis Potensi Ekspor Komoditi Pertanian Unggulan dalam Kerangka Kemandirian Perekonomian Daerah Di Kabupaten Boyolali. Caraka Tani Jurnal IImu-IImu Pertanian Vol XXIV No 1. Maret 2009. Fakultas Pertanian UNS. 
Rustiono.Deddy, 2008.Analisis Pengaruh Investasi, Tenaga Kerja, dan

Pengeluaran Pemerintah Terhadap Pertumbuhan Ekonomi di Provinsi J awa Tengah. Tesis. MIESP UNDIP Semarang

Sadono Sukirno (2008) Makroekonomi teori pengantar edisi ketiga PT. Raja Grafindo Persada Jakarta

Siagian, H. 1989. Pembangunan Ekonomi Dalam Cita-Cita dan Realita. Bandung. Citra Aditya Bakti.

Simanjuntak, J. Payaman 1998. Pengantar Ekonomi SumberDaya Manusia. Jakarta. Lembaga Penerbit Fakultas Ekonomi Universitas Indonesia.

Soeroto.1992, Strategi Pembangunan dan Perencanaan Kesempatan Kerja, Gadja Mada Universitas Pres, Yogyakarta.

Sudarsono, 1983.Pengantar Ekonomi Mikro. Jakarta. BP3ES.

Tarigan, Robinson.(2012). Ekonomi Regional Teori dan Aplikasi. Edisi Revisi. Bumi Aksara. Jakarta.

Todaro, M, P. dan Smith, S.C. (2006).Pembangunan Ekonomi. Jilid 1 Edisi Kesembilan.Erlangga. Jakarta

Tulus TH. Tambunan (2003) Perekonomian Indonesia, beberapa masalah penting. Ghalia Indonesia Jakarta

Winarno WW, (2009). Analis is Ekonometrika dan Statistika Dengan E views. Edisi ke -2. Yogyakarta: UPP STIM YKPN. 